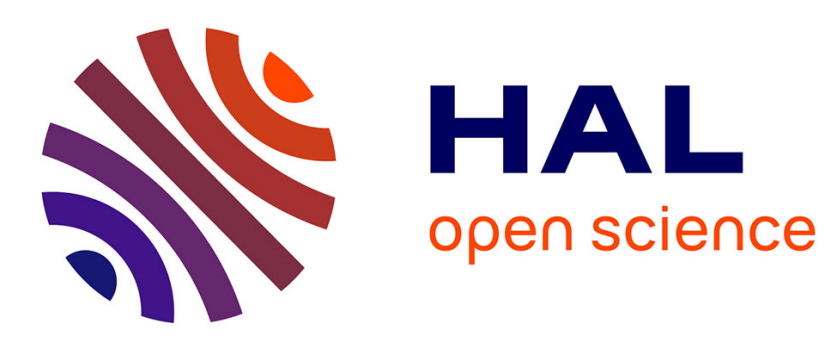

\title{
Household Production in a Collective Model: Some New Results
}

Benoît Rapoport, Catherine Sofer, Anne Solaz

\section{To cite this version:}

Benoît Rapoport, Catherine Sofer, Anne Solaz. Household Production in a Collective Model: Some New Results. Journal of Population Economics, 2011, 24, pp.23-45. hal-00687274

\section{HAL Id: hal-00687274 \\ https://hal.science/hal-00687274}

Submitted on 12 Apr 2012

HAL is a multi-disciplinary open access archive for the deposit and dissemination of scientific research documents, whether they are published or not. The documents may come from teaching and research institutions in France or abroad, or from public or private research centers.
L'archive ouverte pluridisciplinaire HAL, est destinée au dépôt et à la diffusion de documents scientifiques de niveau recherche, publiés ou non, émanant des établissements d'enseignement et de recherche français ou étrangers, des laboratoires publics ou privés. 


\title{
Household Production in a Collective Model: Some New Results
}

\author{
Benoît RAPOPORT (University Paris 1-Panthéon-Sorbonne) \\ Catherine SOFER* (University Paris 1-Panthéon-Sorbonne and Paris School of \\ Economics) \\ Anne SOLAZ (INED)
}

November 2007

\begin{abstract}
In this paper we compare the results of household models estimated on data for labour supplies, domestic work and leisure with those of systems estimated on data for labour supplies alone and which assume non-market time is pure leisure. We extend previous work on collective household decision-making by estimating the Chiappori, Fortin and Lacroix (2002) model on time use data. We show that the derivatives of the household "sharing rule" can be estimated in a similar way to that used in models based only on hours of market work.

Using the 1998 French Time-Use Survey, we provide estimates of labour supply functions assuming first that non-market time is pure leisure and then taking household production into account. The results are similar in both cases, but they are more robust when household production is included. Furthermore, we show that collective rationality is rejected when domestic work is omitted, but not when we account for it.
\end{abstract}

JEL Classification: D13, J22

\footnotetext{
* Centre d'Economie de la Sorbonne, 106-112, bd de l'Hôpital, 75647 PARIS cedex 13, France. Tel: 0033-1-4407-82-58. E-mail: catherine.sofer@univ-paris1.fr
} 


\section{Introduction}

Women's labour supply has increased dramatically during the second half of the twentieth century. ${ }^{1}$ However, time allocations to both market and household work are still highly differentiated by gender (Goldschmidt-Clermont and Pagnossin-Aligisakis, 1995, Rizavi and Sofer, 2008). Understanding how work, market and domestic, is shared within the household is essential for the evaluation of social policy (Sofer, 1999).

A limitation of a number of theoretical and empirical studies on labour supply and the intra-household sharing of work and consumption is the assumption that time outside the market is entirely leisure. Examples include the "collective" model of the household decisionmaking process of Chiappori (1988, 92), Fortin and Lacroix (1997) and Chiappori, Fortin and Lacroix(2002). The estimation of the parameters of a sharing rule in a model that treats nonmarket time as leisure can be expected to yield misleading results if a significant component of that time is devoted to the production of goods and services for consumption by all household members. ${ }^{2}$ Then, the standard collective approach, in which non-market time is assumed to be pure leisure, incorrectly equates a lower female labour supply with more female leisure. Since the allocation of time to household production differs between men and women, the measure of their respective bargaining power via the sharing rule may be subject to a large error. To test this hypothesis, we extend the approach of Chiappori, Fortin and Lacroix (2002) by employing time use data to estimate the sharing rule of a model that takes account of household production. We show how the Chiappori et al. approach can be extended by taking the case of marketable household goods, and how the sharing rule can be recovered for any bounded household production function, and its derivatives estimated in a simple way, as in the case of a model based on data for market labour supplies alone.

Few studies have used time use data to analyse household production in a rigorous manner, including both a theoretical model and empirical estimation ${ }^{3}$. A major difficulty for empirical work of this kind is missing information on the output of household production. As a result, strong assumptions have to be made on household production functions, such constant returns to scale as in Apps and Rees (1996). The main contribution of the present

\footnotetext{
${ }^{1}$ For a discussion of changes in female labor supply since the beginning of the twentieth century, see Marchand and Thélot (1991) and Sofer (2005).

${ }^{2}$ As shown in Apps and Rees (1996).

${ }^{3}$ Examples include the models in Apps and Rees (1996, 2002), Couprie (2007), and, for a mainly empirical approach Aronsson, Daunfeldt and Wikström (2001).
} 
paper is to set out the identification conditions for a more general class of household production functions, and to provide new results based on these conditions.

We first estimate the parameters of the labour supply functions and sharing rule of the Chiappori, Fortin, and Lacroix (2002) model with non-market time treated as pure leisure. We then re-estimate the both sets of parameters taking account of the input of time to household production. The difference between the results gives an indication of the "error" arising from interpreting non-market time as leisure.

Our data come from the INSEE French time-use survey, "Enquête Emploi du temps 1998-1999"4. In addition to income, wages and the usual characteristics of household members, these data provide detailed information on the allocation of time by each household member to different types of household work.

The paper is organised as follows. Section 2 begins with the formulation of a collective model of labour supply with household production. The model is extended to include distribution factors for the identification of the sharing rule. Section 3 presents our econometric model, discusses the time use data for the study, and reports our results. Section 4 concludes.

\section{A Collective Model of Household Labour Supply with Household Production}

\subsection{The basic setting}

As in Apps and Rees (1988) and Chiappori (1988, 1992), we assume household decisions are Pareto-efficient. ${ }^{5}$ The theoretical framework we consider is the collective model with distribution factors ${ }^{6}$ as in Chiappori, Fortin and Lacroix (2002). A distribution factor is assumed to exert an influence upon bargaining power, but not upon prices or preferences. It might, for example, be the sex ratio or divorce laws. The decision process with household production can then be interpreted as follows: household members agree on some efficient production plan and intra-household distribution of resources. Each member then freely chooses his or her leisure and domestic and market consumption bundle subject to his/her specific budget constraint. Rather than assuming household production exhibits constant returns, we allow for a more flexible form of technology. In fact, we only assume that the

\footnotetext{
${ }^{4}$ The INSEE (Institut National de la Statistique et des Etudes Economiques) is the French Institute for Statistics and Economic Studies. We are grateful to the French Research Center LASMAS for making the data available to us.

${ }^{5}$ See also Samuelson (1956).

${ }^{6}$ As originally introduced in bargaining models by Manser and Brown (1980) and Mc Elroy end Horney (1981).
} 
production function is bounded on $[0, T] \times[0, T]$, where $T$ represents the total individual available time, and that the Hotelling lemma can be applied.

We also assume, as in Chiappori (1997), that household production is marketable ${ }^{7}$. This means that domestic goods have perfect market substitutes, and that domestic production in any quantity can be bought and sold at market prices by all households. This is, of course, a simplifying assumption, made to ensure a tractable solution. The main objection to the assumption is not that household goods have no market substitutes. The usual goods and services listed in time use surveys (time spent with children, cooking, washing, etc.) all have nearly perfect market substitutes that are widely bought by households ${ }^{8}$. The problem is selling availability: households that could efficiently produce more domestic goods than they want to consume would have difficulties in selling them, at least in developed countries, though a few exchanges (for instance of childcare services) do occasionally take place between households. ${ }^{9}$ The fact that domestic output is generally not measured in time use surveys - data on individual time allocations are collected but not on outputs or raw inputs ${ }^{10}$ necessitates special assumptions of the kind we have made here.

If all households are assumed to face the same market prices for domestic goods, there is no further restriction in assuming that the household produces an aggregate good, $Y$, with a price normalised to 1 , consistent with the price of an aggregate market good. With this assumption, the consumption of domestic goods needs not be distinguished from that of market goods. Both can be merged into a single aggregate in the utility function ${ }^{11}$.

In addition, following Chiappori, Fortin and Lacroix (2002), we do not assume that the individual shares of exogenous income are observable. In practice, household non-labour income cannot easily be assigned to individual household members, both in survey data and in real life. Since individual data on non-labor incomes are not available for the present study, we assume that at least one distribution factor can be observed.

Formally, the household consists of two individuals, male and female. Individual $i, i=$ $m, f$, has a utility function $u_{i}\left(\right.$.) defined on observed leisure, $l_{i}$, unobserved consumption of a Hicksian composite good that is either produced at home or purchased in the market, $C_{i}$, and

\footnotetext{
${ }^{7}$ As in the farm production model of the development literature.

${ }^{8}$ This could be questionable for activities which have a strong component of leisure or "own" consumption, such as time spent playing with children or cooking for friends. In these cases, there is joint production (see Pollak and Wachter, 1975). However, activities of this kind represent only a small proportion of total household "tasks".

${ }^{9}$ See, for example, Lacroix, Picot, Sofer, 1998.

10 In France, an exception is the 1989 Modes de Vie survey, but it suffers from important drawbacks for our purpose (see Lecocq, 2001)

${ }^{11}$ As in Gronau (1977)
} 
on a vector of individual and household characteristics, $z$. We assume that all goods are private $^{12}$. The quantity of the home-produced good is denoted by $Y$ and produced by time inputs of household members, $t_{i}, i=m, f$, according to the production function $F\left(t_{f}, t_{m}\right)$. We thus have:

$$
u_{i}=u_{i}\left(l_{i}, C_{i} ; \mathbf{z}\right)
$$

Profit, $\Pi$, or net value of domestic production, is given by

$$
\Pi=Y-w_{f} t_{f}-w_{m} t_{m}
$$

where $w_{f}$ and $w_{m}$ are the wage rates of $f$ and $m$, respectively. This imputed profit is added to the other income flows.

We denote total time available by $T$, labour supply by $L_{i}$, and total working time (domestic labour + market labour supply) by $h_{i}$. Thus we have the time constraint $h_{i}+l_{i}=T$, where $h_{i}=t_{i}+L_{i}$.

The household maximises what can be considered a generalized ${ }^{13}$ weighted utilitarian household welfare function:

$$
\text { (P0) } \underset{L_{f}, L_{m}, C_{f}, C_{m}}{\operatorname{Max}} \mu(.) u_{f}\left(l_{f}, C_{f} ; \mathbf{z}\right)+(1-\mu(.)) u_{m}\left(l_{m}, C_{m} ; \mathbf{z}\right)
$$

subject to the constraint

$$
\sum_{i=f, m} C_{i}=\sum_{i=f, m} L_{i} w_{i}+y+F\left(t_{f}, t_{m}\right)
$$

where $y$ is non-labour income and $\mu=\mu\left(w_{f}, w_{m}, y, s_{1}, \ldots, s_{r, \ldots}, s_{R}, z_{1}, \ldots, z_{n}, \ldots, z_{N}\right)$ is a continuously differentiable weighting factor contained in $[0,1] . \mathbf{s}$ is a R-vector of distribution factors. By definition, the vector s only appears in $\mu$ (.). As such, changes in the s variables do not affect the Pareto frontier but only the equilibrium location on it, through the resulting changes in shares of full income.

The above constraint can be rewritten as

$$
\sum_{i=f, m} C_{i}=\sum_{i=f, m} h_{i} w_{i}+y+\Pi
$$

Following Chiappori, Fortin and Lacroix (2002), we assume that the sharing rule applies to non-labour market income, $y+\Pi$.

\footnotetext{
${ }^{12}$ It can be argued that both market goods and domestic goods may have a public component. A few papers deal with public goods besides private consumption (see, for example, Chiappori, Blundell and Meghir, 2002, or Donni, 2003), but they do not include domestic production. Couprie (2007) assumes that market goods are privately consumed, and only domestic goods are assumed to be public goods.

${ }^{13}$ Here the weights are a function of prices, among other variables
} 
Formally, the maximisation problem becomes

(P1) $\quad \operatorname{Max}_{t_{f}, t_{m}} \Pi=Y-w_{f} t_{f}-w_{m} t_{m}$

which gives solutions:

$$
\begin{aligned}
& t_{f}=t_{f}\left(w_{m}, w_{f}\right) \\
& t_{m}=t_{m}\left(w_{m}, w_{f}\right) \\
& \Pi^{*}=\Pi\left(w_{m}, w_{f}\right)
\end{aligned}
$$

and for individual $i, i=f, m$ :

$$
\operatorname{Max}_{C_{i}, L_{i}, Y_{i}} u_{i}\left(C_{i}, l_{i} ; \mathbf{z}\right)
$$

subject to

$$
C_{i}=H_{i} w_{i}+\psi_{i}
$$

where $\psi_{i}$ denotes $i$ 's non-labour market income and

$\psi_{f}+\psi_{m}=y+\Pi^{*}$

In the following we set $\psi=\psi_{f}$, where $\psi$ is a function of $w_{f}, w_{m}, y, \mathbf{s}, \mathbf{z}$. If working time, either in the market or at home, is valued at its opportunity cost, $\psi$ can be considered as the extra income allocated to the wife from the sharing of "non labour-market income", where the latter is the sum of non-labour income and profit from household production. Thus the shares are a function of wages, non-labour income, preferences and distribution factors.

Total labour supplies have the form:

$$
\begin{aligned}
& h^{f}=L^{f}\left(w_{f}, \psi\left(w_{f}, w_{m}, y, \ldots s_{l} \ldots ; \mathbf{z}\right) ; \mathbf{z}\right) \\
& h^{m}=L^{m}\left(w_{m}, \Pi\left(w_{f}, w_{m} ; \mathbf{c}, \mathbf{z}\right)+y-\psi\left(w_{f}, w_{m}, y, \ldots s_{l} \ldots ; \mathbf{z}\right) ; \mathbf{z}\right)
\end{aligned}
$$

In a model that treats domestic production as a component of leisure, the $t_{i}$ is set to zero and $h_{i}$ is equal to market labour supply $L_{i}, \Pi$ is zero, and we obtain the model in Chiappori, Fortin Lacroix (2002). Here, some of the partials with respect to wages will now depend on $t_{i}$. Note that $\Pi$ is endogenously determined but not observed because the output of household production is not observed.

We now turn to the identification conditions for the sharing rule. The idea is to show first that it is always possible to estimate the derivatives of the sharing rule under the substitutability assumption, and second to make explicit the differences between models with and without household production. 


\subsection{Identification of the sharing rule}

From the program (P1), we obtain the following proposition:

Proposition 1. If: (i) household goods are marketable, (ii) the production technologies of domestic goods is bounded on the space of available times, (iii) the derivatives of the profit function exist, given that the allocation of time to household tasks, market work and "pure" leisure is observable, and (iv) there exists at least one observable distribution factor, then the sharing rule can be recovered up to a constant.

This result extends that of Apps and Rees (1988, 1996, 1997). Also note that Chiappori's (1997) result is in fact a special case here, with a weak empirical content: with one aggregate domestic good produced with a constant return to scales technology, the marginal production cost, $c$, is a scalar. With an exogenous price of the domestic good, $p$, the only solutions for the allocation of time are corner solutions. Domestic production is either zero or totally indeterminate, or there is complete specialization in domestic work by at least one household member (cases $p<c, p=c$ or $p>c$, respectively). Equality between unit cost and unit price would hold only for a minority of households, for which the model admits no predictable result. The other cases have no real empirical content for, in real life, both members of the household do participate in household production, even if this participation is not equally distributed.

Here we only assume that the production function is bounded on $[0, T] \times[0, T]$, the space of available times, so that profit has a maximum value (possibly zero), and that the derivatives of the profit function exist, which allows us to apply the Hotelling lemma. These assumptions are not very restrictive and are, in particular, verified by most of the usual technologies. They also allow for corner solutions, that is, for complete specialisation of one or both spouses.

\section{Proof:}

It can be seen immediately that $\psi=\psi_{f}$, such that $\psi_{m}+\psi_{f}=\Pi+y$, exhibits similar properties as the sharing of exogenous income, $\varphi$, in Chiappori, Fortin and Lacroix (2002). Considering $\psi$ as the "sharing rule", and to the extent that household time and labour market time are both observable, an extension of the results in Chiappori et al. (2002) applies here: $\psi_{i}$ can be recovered up to a constant using the partials of the sharing rule. The "standard 
labour supply" case, which omits domestic production, can be obtained by setting $t_{i}$, domestic time, to zero (see proof in Appendix 1).

Note also that testable restrictions can be obtained in the model above, especially when there is more than one distribution factor.

The above result implies a corollary:

Corollary 1 The "sharing rule" can, in the sense defined above, be recovered without further information or specific assumptions ${ }^{14}$ regarding the "household production side" of the process, apart from the observed time allocations of each household member to household and market work (only total working time of each kind ${ }^{15}$ by each household member is required).

As in much of the literature, ${ }^{16}$ we introduce, through the variables appearing in functions $\psi_{\text {i }}$, the assumption that only market characteristics matter in bargaining power, i.e., that domestic productivities play no role in the sharing of full income. This assumption could, in future work, be tested as it amounts to assuming that a rise in $\Pi$, due to an increase in the domestic productivity of either household member, should have the same impact as an increase in $y$. The assumption therefore implies testable restrictions on the partial derivatives of $\psi_{i}, \Pi$, and $\varphi_{i}$.

\section{Econometric models, data and results}

\subsection{Econometric specification}

We estimate male and female labour supply equations simultaneously, using the generalised method of moments (GMM). GMM provides efficient estimates of the parameters of simultaneous equations and has two main advantages: first, it allows us to take into account the possible correlation between the error terms in the male and female labour supply equations; and second, the method computes efficient estimators even when errors are heteroskedastic of an unknown form (which is not, for example, the case for 3SLS). We estimate two sets of models which we label as follows:

Model 1: the "traditional" labour supply model in which work is measured as time allocated to the labour market. Labour supply can be computed in minutes from the data

\footnotetext{
${ }^{14}$ More specific assumptions about household production functions may of course lead to interesting results, as in Donni (2008), and in Rapoport and Sofer (2004) where specifying a CES production function permits the derivation of results for the case of non-marketable household goods.

${ }^{15}$ From the proof in Appendix 1, it can be seen that not only the sum of each type of labour input must be observed, but also each type must be observed separately in order to identify the derivatives of the sharing rule.

16 An exception is Bourguignon and Chiuri (2005)
} 
reported in activity booklet (see below). These data give the time spent in market work by the responding individual on the day of observation. This is usually an accurate average indicator of working hours ${ }^{17}$ (see Robinson et al., 2001).

Model 2: a model in which work is measured as total labour supply, computed as the sum of time spent in the labour market and time devoted to household production.

Time allocations to market and domestic work are computed from the activity booklet which reports time use for day of interview, which may be either a week day or a weekend day. We control for this by adding a dummy variable that takes a value of 1 if the day of observation is a week day.

Model 1 implicitly assumes that non-market time is pure leisure, and therefore excludes domestic work, whereas model 2 takes time inputs in household production into account. For each type of model we present two sets of results. We first estimate the model on a dataset for a sample that includes parents with children under 3 (models 1a and 2a) and then on a sample that excludes them (models $1 \mathrm{~b}$ and $2 \mathrm{~b}$ ). Our purpose in estimating models $1 \mathrm{~b}$ and $2 \mathrm{~b}$ is to check for the possiblity that the public good nature of the consumption of domestic goods might bias the results, as young children could be viewed as a public good resulting in a specific division of labour between parents.

As unobserved individual characteristics explaining labour supply may also be correlated with wages and non-labour income ${ }^{18}$, these regressors are instrumented. We include as instruments variables that are generally found to be correlated both with wages and nonlabour income: employment sector (public sector, private sector or self employed) and geographical area: living in a small town or in the countryside, as opposed to living in a big town (in which wages are higher on average). We also use more flexible functional forms of education and age in specifying the equations for wages and non-labour income than for labour supply (a second-order polynomial of education and a fourth-order polynomial of age). In particular, we include age as a proxy for professional experience in explaining wages and asset accumulation and therefore non labour income. Information on parents and on inheritance are generally good instruments for non-labour income. Unfortunately, our data base does not offer this information. As a proxy, we use dummies indicating whether or not

\footnotetext{
${ }^{17}$ We also tried using annual working hours, as in Chiappori, Fortin and Lacroix (2002). The results, which are not reported here, are very similar to those from model 1 .

${ }^{18}$ Non labour income is known only at the household level (not at the individual level). Also, for some households, only labour income brackets are known. For these households, labour income was estimated using a
} 
the workers are foreign-born. These dummies may also capture some possible discrimination on the labour market. In total, we have 16 identifying instruments. We decided not to instrument the number of children: the estimates are robust to this choice. Finally, the Hansen test does not reject the over identification restrictions for any of our four models (see last line of Table 3.2).

Concerning the robustness of the results, we tested two estimation methods (3SLS and GMM), several definitions of domestic time (by including and then excluding activities that are likely to be more enjoyable, such as games with children and gardening) and several definitions of working time (by including and then excluding commuting time and lunch time). The results are not affected by these specifications. Models $1 \mathrm{~b}$ and $2 \mathrm{~b}$ also provide some evidence of the robustness of our results.

For the distribution factor we use the sex ratio, which is computed at the "departmental"19 level from French National Statistics in 1999. This is the ratio of males of age $\mathrm{X}$ to the total population of age $\mathrm{X}$.

We estimate female and male labour supply and total work equations of the following form

$$
\begin{aligned}
& h^{f}=f_{0}+f_{1} \ln w_{f}+f_{2} \ln w_{m}+f_{3} y+f_{4} s+\mathbf{f}_{5}^{\prime} \mathbf{z}+f_{6} \ln w_{f} \ln w_{m} \\
& h^{m}=m_{0}+m_{1} \ln w_{f}+m_{2} \ln w_{m}+m_{3} y+m_{4} s+\mathbf{m}_{5}{ }^{\prime} \mathbf{z}+m_{6} \ln w_{f} \ln w_{m}
\end{aligned}
$$

from which we can compute

$$
\begin{aligned}
& A=\frac{h_{w_{m}}^{f}}{h_{y}^{f}}=\frac{f_{2}+f_{6} \ln w_{f}}{f_{3} w_{m}} \\
& B=\frac{h_{w_{f}}^{m}}{h_{y}^{m}}=\frac{m_{1}+m_{6} \ln w_{m}}{m_{3} w_{f}} \\
& C=\frac{h_{s}^{f}}{h_{y}^{f}}=\frac{f_{4}}{f_{3}} \\
& D=\frac{h_{s}^{m}}{h_{y}^{m}}=\frac{m_{4}}{m_{3}}
\end{aligned}
$$

If we let $\Delta=f_{3} m_{4}-m_{3} f_{4}$, then ${ }^{20}$

$$
\psi_{y}=\frac{D}{D-C}=\frac{f_{3} m_{4}}{\Delta}
$$

larger survey from the INSEE ("Enquête sur l'emploi 1999", i.e. Labour Force Survey 1999). All the information about the estimations is available from the authors.

${ }^{19}$ France is divided into one hundred areas called departments.

${ }^{20}$ See Appendix 1. 


$$
\begin{aligned}
& \psi_{s}=\frac{C D}{D-C}=\frac{f_{4} m_{4}}{\Delta} \\
& \psi_{w_{m}}=\frac{A D}{D-C}=\frac{\left(f_{2}+f_{6} \ln w_{f}\right) m_{4}}{w_{m} \Delta} \\
& \psi_{w_{f}}=\frac{B C}{D-C}-t_{f}=\frac{\left(m_{1}+m_{6} \ln w_{m}\right) f_{4}}{w_{f} \Delta}-t_{f}
\end{aligned}
$$

All derivatives of the sharing rule are computed at sample means using these expressions.

\subsection{Data}

The French Time-Use survey (Enquête Emplois du temps) conducted by INSEE in 1998-99 aimed to measure daily activities as precisely as possible. The survey was conducted in successive stages throughout the year, so as to avoid seasonal effects. On the day of the survey, respondents were asked to record their activities, indicating the time spent on each in 10-minute intervals. Where more than one activity took place at the same time, two activities were reported, one being the main activity and the other a secondary activity. All household members aged 15 and above were surveyed.

The survey includes:

- A base of 8,186 households, of which 7,460 are complete (i.e., in which all household members filled in a time use booklet and an individual questionnaire);

- A base of 20,370 individuals, among whom 16,442 are at least 15 years old;

- A base of activities, containing one observation per completed booklet line, with 316,097 observations. 144 different types of activities were listed. They have been regrouped on the basis of activities of the same type by INSEE. The list of the activities which are used here is given in Appendix 2.

We first select a sample of two-earner couples (married or cohabiting) in which both partners report a paid activity. Both must have filled out the questionnaire booklet on the same day. Our full sample (complete observations) consists of 1414 couples. Models 1a and $2 \mathrm{a}$ are estimated using this sample. We also selected a sub-sample of households on the criterion that there were no children under 3 present. Models $1 b$ and $2 b$ are estimated on this sub-sample. Given that secondary activities are frequently not reported in the time use booklets, we restrict our analysis to main activities. The descriptive statistics of variables used in the estimations for the complete sample appear in Table 3.1 below. 
Table 3.1 Sample description, 1414 couples (complete observations)

\begin{tabular}{|c|c|c|}
\hline Variable & $\begin{array}{c}\text { Mean } \\
\text { (weighted) }\end{array}$ & $\begin{array}{l}\text { Standard } \\
\text { Deviation }\end{array}$ \\
\hline \multicolumn{3}{|l|}{ Dependent variables } \\
\hline 1 Man's daily labour market hours of work & 4.75 & 4.09 \\
\hline Woman's daily labour market hours of work & 3.98 & 3.78 \\
\hline Man's daily domestic hours of work & 2.67 & 2.38 \\
\hline Woman's daily domestic hours of work & 4.29 & 2.59 \\
\hline 2 Man's daily total (domestic + labour market) hours of work & 7.42 & 3.37 \\
\hline Woman's daily total (domestic + labour market) hours of work & 8.25 & 2.97 \\
\hline \multicolumn{3}{|l|}{ Endogenous variables } \\
\hline Man's hourly wage (in Euros) & 9.47 & 5.52 \\
\hline Woman's hourly wage (in Euros) & 8.08 & 5.35 \\
\hline Monthly non-labour income (in Euros) & 306.33 & 514.4 \\
\hline (in thousand francs) & 2.01 & 3.37 \\
\hline \multicolumn{3}{|l|}{ Exogenous variables } \\
\hline Sex ratio $(H / F)$ & 0.50 & 0.01 \\
\hline Number of children up to 3 years old & 0.13 & 0.34 \\
\hline Number of children between 3 and 15 years old & 1.21 & 1.06 \\
\hline Woman's age & 38.79 & 8.63 \\
\hline Man's age & 40.78 & 8.79 \\
\hline Man's education from 0 (no diploma) to 8 (“Grandes écoles") & 3.56 & 2.22 \\
\hline Woman's education from 0 (no diploma) to 8 (“Grandes écoles") & 3.76 & 2.17 \\
\hline Region 1: Paris and suburbs (dummy) & 0.40 & 0.49 \\
\hline Region 2: North (dummy) & 0.05 & 0.23 \\
\hline Region 3: East (dummy) & 0.11 & 0.31 \\
\hline Region 4: West (dummy) & 0.14 & 0.35 \\
\hline Region 5: South -West (dummy) & 0.09 & 0.29 \\
\hline Region 6: Center East (dummy) & 0.12 & 0.32 \\
\hline Region 7: Mediterranean (reference) & 0.08 & 0.28 \\
\hline Number of rooms in the dwelling & 4.31 & 1.29 \\
\hline Individual house (dummy) & 0.68 & 0.47 \\
\hline \multicolumn{3}{|l|}{ Instruments (others) } \\
\hline \multicolumn{3}{|l|}{ Man's age (polynomial equation, $4^{\text {th }}$ degree) } \\
\hline \multicolumn{3}{|l|}{ Man's education (polynomial equation, 2nd degree) } \\
\hline \multicolumn{3}{|l|}{ Woman's age (polynomial equation, $4^{\text {th }}$ degree) } \\
\hline \multicolumn{3}{|l|}{ Woman's education (polynomial equation, 2nd degree) } \\
\hline Man born abroad (dummy) & 0.09 & 0.29 \\
\hline Woman born abroad (dummy) & 0.07 & 0.26 \\
\hline Man self-employed (dummy) & 0.03 & 0.180 \\
\hline Woman self-employed (dummy) & 0.01 & 0.12 \\
\hline Man works in the public sector (dummy) & 0.30 & 0.46 \\
\hline Woman works in the public sector (dummy) & 0.38 & 0.49 \\
\hline Living in a small town (dummy) & 0.16 & 0.37 \\
\hline Living in a countryside area (dummy) & 0.26 & 0.44 \\
\hline
\end{tabular}




\subsection{Parameter estimates}

Table 3.2 reports the parameters of the two sets of models, models 1a and 1b (without household production) and model $2 \mathrm{a}$ and $2 \mathrm{~b}$ (with household production). The results of the models estimated on the sub-sample of households with no children under three (models $1 \mathrm{~b}$ and $2 b$ ) do not differ significantly from those estimated on the full sample (models 1a and 2a), except for the effects of wages, which are generally slightly smaller. The same holds for the sign of the parameters when comparing the models with and without domestic production, though the negative effects of wages upon male and female hours of work are sensibly higher in the models without household production than in the models that include household production. One noticeable difference between the two sets of models is in the effect of the female wage on husband's labour supply, which is much lower in models 1a and 1b. As expected, non-labour income has a significant negative impact of about the same size on labour market time and total working time for both women and men, though, for men, its impact is slightly higher on market time.

The sex ratio also has the expected sign (negative on female work, positive on male work) but is rarely significant (it is found significant only on male work in model 2a).

Children, not surprisingly, are found to have a different and sometimes opposite effects in models $1 \mathrm{a}$ and $1 \mathrm{~b}$, on one hand, and in models $2 \mathrm{a}$ and $2 \mathrm{~b}$, on the other hand, on their parents' time. As expected, the effects on mothers and fathers are found to be very different: the impact of a child of any age on fathers' working time of both kinds is positive, with the effect being stronger and more significant when domestic production is taken into account. This is particularly true if children under 3 years are present. This means that fathers simultaneously increase market and household work, especially when they have young children. For mothers, the effects of children on market and domestic work, while nearly always highly significant, can go in opposite directions: children under three have a strong negative effect on female market work (but no effect if they are older), and children any age have a strong positive impact on total female work. Though mothers, like fathers, increase their total hours of work when children are present, unlike fathers they strongly decrease market work.

Education is found to have a significant positive impact upon work in all models only for women: for women, education increases market work, and has a slightly larger effect when they have no children under 3. This increase in female market work is not offset by a decrease in hours of household work. 
Table 3.2 Comparative GMM estimates: Models 1a, 1b, 2a and 2b

\begin{tabular}{|c|c|c|c|c|c|c|c|c|}
\hline & \multicolumn{4}{|c|}{ Without domestic production } & \multicolumn{4}{|c|}{ With domestic production } \\
\hline & \multicolumn{2}{|c|}{$\begin{array}{l}\text { Model 1a } \\
\text { Whole sample }\end{array}$} & \multicolumn{2}{|c|}{$\begin{array}{l}\text { Model 1b } \\
\text { No children under } 3\end{array}$} & \multicolumn{2}{|c|}{$\begin{array}{l}\text { Model 2a } \\
\text { Whole sample }\end{array}$} & \multicolumn{2}{|c|}{$\begin{array}{l}\text { Model 2b } \\
\text { No children under } 3\end{array}$} \\
\hline & Men & Women & Men & Women & Men & Women & Men & Women \\
\hline $\ln w_{f}\left(m_{1} ; f_{1}\right)$ & $\begin{array}{c}-26.15 * * * \\
(7.16) \\
\end{array}$ & $\begin{array}{c}-13.43 * * \\
(5.69) \\
\end{array}$ & $\begin{array}{c}-21.86 * * * \\
(5.90) \\
\end{array}$ & $\begin{array}{c}-11.13 * * \\
(5.65) \\
\end{array}$ & $\begin{array}{c}-13.54 * * \\
(5.41)\end{array}$ & $\begin{array}{c}-12.02 * * \\
(5.00)\end{array}$ & $\begin{array}{c}-12.94 * * * \\
(4.83) \\
\end{array}$ & $\begin{array}{c}-10.45^{* *} \\
(4.49) \\
\end{array}$ \\
\hline $\ln w_{h}\left(m_{2} ; f_{2}\right)$ & $\begin{array}{c}-25.24 * * * \\
(6.90)\end{array}$ & $\begin{array}{c}-12.29 * * \\
(4.74)\end{array}$ & $\begin{array}{l}-22.27 * * * \\
(5.70)\end{array}$ & $\begin{array}{c}-10.06 * * \\
(4.65)\end{array}$ & $\begin{array}{c}- \\
14.78^{* * * *} \\
(5.17)\end{array}$ & $\begin{array}{c}-11.78 * \\
(4.60)\end{array}$ & $\begin{array}{c}-15.07 * * * \\
(4.61)\end{array}$ & $\begin{array}{c}-10.19 * * \\
(4.15)\end{array}$ \\
\hline $\begin{array}{l}\ln w_{h} \times \ln w_{f}\left(m_{6} ;\right. \\
\left.f_{6}\right)\end{array}$ & $\begin{array}{c}6.54 * * * \\
(1.77) \\
\end{array}$ & $\begin{array}{l}3.18 * * \\
(1.38) \\
\end{array}$ & $\begin{array}{c}5.57 * * * \\
(1.46) \\
\end{array}$ & $\begin{array}{l}2.51 * * \\
(1.22) \\
\end{array}$ & $\begin{array}{c}3.63 * * * \\
(1.34) \\
\end{array}$ & $\begin{array}{c}2.88 * * \\
(1,21) \\
\end{array}$ & $\begin{array}{c}3.57 * * * \\
(1,19) \\
\end{array}$ & $\begin{array}{l}2.45 * * \\
(1,09) \\
\end{array}$ \\
\hline $\begin{array}{l}\text { Non-labour } \\
\text { income }\left(m_{3} ; f_{3}\right)\end{array}$ & $\begin{array}{c}-0.61 * * \\
(0.27)\end{array}$ & $\begin{array}{c}-0.43 * * \\
(0.22) \\
\end{array}$ & $\begin{array}{c}-0.57 * * \\
(0.23)\end{array}$ & $\begin{array}{c}-0.44 * * \\
(0.20)\end{array}$ & $\begin{array}{l}-0.40^{*} \\
(0.21)\end{array}$ & $\begin{array}{c}-0.53 * * * \\
(0,20)\end{array}$ & $\begin{array}{c}-0.41 * * \\
(0,18)\end{array}$ & $\begin{array}{c}-0.45^{* *} \\
(0,18)\end{array}$ \\
\hline $\begin{array}{l}\text { Sex ratio }\left(m_{4} ;\right. \\
\left.f_{4}\right)\end{array}$ & $\begin{array}{c}15.64 \\
(10.86) \\
\end{array}$ & $\begin{array}{l}-12.60 \\
(9.18) \\
\end{array}$ & $\begin{array}{c}12.42 \\
(11.06) \\
\end{array}$ & $\begin{array}{r}-14.51 \\
(9.52) \\
\end{array}$ & $\begin{array}{c}14.59^{*} \\
(8.84) \\
\end{array}$ & $\begin{array}{r}-11.97 \\
(8.14) \\
\end{array}$ & $\begin{array}{l}15.53 \\
(9.53) \\
\end{array}$ & $\begin{array}{l}-13.04 \\
(8.49) \\
\end{array}$ \\
\hline Child 3-15 & $\begin{array}{l}0.33^{*} \\
(0.19)\end{array}$ & $\begin{array}{c}0.00 \\
(0.17)\end{array}$ & $\begin{array}{l}0.32 * \\
(0.17)\end{array}$ & $\begin{array}{l}-0.01 \\
(0.16)\end{array}$ & $\begin{array}{c}0.40 * * * \\
(0.15)\end{array}$ & $\begin{array}{c}0.51 * * * \\
(0.14)\end{array}$ & $\begin{array}{c}0.44 * * \\
(0.14)\end{array}$ & $\begin{array}{c}0.47 * * * \\
(0.13)\end{array}$ \\
\hline Child under 3 & $\begin{array}{c}0.43 \\
(0.33) \\
\end{array}$ & $\begin{array}{c}-0.67 * * \\
(0.33) \\
\end{array}$ & & & $\begin{array}{c}0.97 * * * \\
(0.26) \\
\end{array}$ & $\begin{array}{c}1.27 * * * \\
(0.25) \\
\end{array}$ & & \\
\hline Education & $\begin{array}{c}0.02 \\
(0.08)\end{array}$ & $\begin{array}{c}0.23 * * \\
(0.10)\end{array}$ & $\begin{array}{c}0.05 \\
(0.08) \\
\end{array}$ & $\begin{array}{c}0.31 * * * \\
(0.11)\end{array}$ & $\begin{array}{c}0.01 \\
(0.06)\end{array}$ & $\begin{array}{l}0.13^{*} \\
(0.08)\end{array}$ & $\begin{array}{c}0.01 \\
(0.06)\end{array}$ & $\begin{array}{l}0.15^{*} \\
(0.08)\end{array}$ \\
\hline Age & $\begin{array}{c}0.03 \\
(0.02) \\
\end{array}$ & $\begin{array}{c}0.04 * * \\
(0.02)\end{array}$ & $\begin{array}{l}0.03 * \\
(0.02)\end{array}$ & $\begin{array}{c}0.05^{* *} \\
(0.02) \\
\end{array}$ & $\begin{array}{l}0.03 * \\
(0.02) \\
\end{array}$ & $\begin{array}{c}0.06 * * * \\
(0.02)\end{array}$ & $\begin{array}{c}0.03 * * \\
(0.01) \\
\end{array}$ & $\begin{array}{c}0.06^{* * * *} \\
(0.02)\end{array}$ \\
\hline Region 1 & $\begin{array}{c}0.19 \\
(0.46)\end{array}$ & $\begin{array}{c}0.35 \\
(0.44)\end{array}$ & $\begin{array}{c}0.29 \\
(0.48)\end{array}$ & $\begin{array}{c}0.53 \\
(0.44) \\
\end{array}$ & $\begin{array}{c}0.40 \\
(0.36) \\
\end{array}$ & $\begin{array}{c}0.63 * * \\
(0.35)\end{array}$ & $\begin{array}{c}0.49 \\
(0.39) \\
\end{array}$ & $\begin{array}{c}0.88 * * \\
(0.37)\end{array}$ \\
\hline Region 2 & $\begin{array}{c}-0.54 \\
(0.60) \\
\end{array}$ & $\begin{array}{c}-0.48 \\
(0.56) \\
\end{array}$ & $\begin{array}{l}-0.71 \\
(0.66) \\
\end{array}$ & $\begin{array}{l}-0.45 \\
(0.59) \\
\end{array}$ & $\begin{array}{c}0.08 \\
(0.54) \\
\end{array}$ & $\begin{array}{c}0.07 \\
(0.45) \\
\end{array}$ & $\begin{array}{c}0.11 \\
(0.62) \\
\end{array}$ & $\begin{array}{c}0.40 \\
(0.48) \\
\end{array}$ \\
\hline Region 3 & $\begin{array}{c}0.09 \\
(0.52) \\
\end{array}$ & $\begin{array}{c}0.78 \\
(0.49) \\
\end{array}$ & $\begin{array}{c}0.38 \\
(0.53) \\
\end{array}$ & $\begin{array}{l}1.03 * * \\
(0.50) \\
\end{array}$ & $\begin{array}{c}0.31 \\
(0.43) \\
\end{array}$ & $\begin{array}{c}1.02 * * * \\
(0.39)\end{array}$ & $\begin{array}{c}0.49 \\
(0.47) \\
\end{array}$ & $\begin{array}{c}1.38 * * * \\
(0.42)\end{array}$ \\
\hline Region 4 & $\begin{array}{l}-0.40 \\
(0.52) \\
\end{array}$ & $\begin{array}{l}-0.12 \\
(0.49) \\
\end{array}$ & $\begin{array}{l}-0.34 \\
(0.55) \\
\end{array}$ & $\begin{array}{l}-0.02 \\
(0.49) \\
\end{array}$ & $\begin{array}{l}-0.19 \\
(0.43) \\
\end{array}$ & $\begin{array}{c}0.07 \\
(0.38) \\
\end{array}$ & $\begin{array}{l}-0.20 \\
(0.47) \\
\end{array}$ & $\begin{array}{c}0.24 \\
(0.40) \\
\end{array}$ \\
\hline Region 5 & $\begin{array}{l}-0.28 \\
(0.56) \\
\end{array}$ & $\begin{array}{l}-0.26 \\
(0.49) \\
\end{array}$ & $\begin{array}{c}0.05 \\
(0.58) \\
\end{array}$ & $\begin{array}{c}-0.14 \\
(0.48) \\
\end{array}$ & $\begin{array}{c}0.34 \\
(0.44)\end{array}$ & $\begin{array}{c}0.27 \\
(0.39) \\
\end{array}$ & $\begin{array}{c}0.50 \\
(0.47) \\
\end{array}$ & $\begin{array}{c}0.55 \\
(0.41) \\
\end{array}$ \\
\hline Region 6 & $\begin{array}{l}-0.24 \\
(0.53)\end{array}$ & $\begin{array}{c}0.46 \\
(0.52) \\
\end{array}$ & $\begin{array}{l}-0.09 \\
(0.57) \\
\end{array}$ & $\begin{array}{c}0.55 \\
(0.54) \\
\end{array}$ & $\begin{array}{c}0.24 \\
(0.39) \\
\end{array}$ & $\begin{array}{c}0.93 * * \\
(0.39)\end{array}$ & $\begin{array}{c}0.35 \\
(0.45) \\
\end{array}$ & $\begin{array}{c}1.22 * * * \\
(0.43)\end{array}$ \\
\hline Weekday & $\begin{array}{c}5.42 * * * \\
(0.22) \\
\end{array}$ & $\begin{array}{c}4.31 * * * \\
(0.20) \\
\end{array}$ & \begin{tabular}{|l|}
$5.43 * * *$ \\
$(0.23)$ \\
\end{tabular} & $\begin{array}{l}4.43 * * * \\
(0.21) \\
\end{array}$ & $\begin{array}{c}4.08 * * * \\
(0.21) \\
\end{array}$ & $\begin{array}{c}3.11 * * * \\
(0.20) \\
\end{array}$ & $\begin{array}{c}4.07 * * * \\
(0.22)\end{array}$ & $\begin{array}{l}3.18 * * \\
(0.21) \\
\end{array}$ \\
\hline $\begin{array}{l}\text { Number of } \\
\text { rooms }\end{array}$ & $\begin{array}{c}0.18 \\
(0.13) \\
\end{array}$ & $\begin{array}{c}0.04 \\
(0.11) \\
\end{array}$ & $\begin{array}{l}0.22 \\
(0.14) \\
\end{array}$ & $\begin{array}{l}0.04 \\
(0.12) \\
\end{array}$ & $\begin{array}{l}0.18^{*} \\
(0.11) \\
\end{array}$ & $\begin{array}{c}0.06 \\
(0.10) \\
\end{array}$ & $\begin{array}{l}0.19 * \\
(0.11) \\
\end{array}$ & $\begin{array}{c}0.06 \\
(0.10) \\
\end{array}$ \\
\hline House & $\begin{array}{l}-0.41 \\
(0.30)\end{array}$ & $\begin{array}{l}-0.18 \\
(0.25) \\
\end{array}$ & $\begin{array}{l}-0.51 * \\
(0.30) \\
\end{array}$ & $\begin{array}{l}-0.27 \\
(0.27) \\
\end{array}$ & $\begin{array}{c}0.16 \\
(0.23) \\
\end{array}$ & $\begin{array}{c}0.30 \\
(0.21) \\
\end{array}$ & $\begin{array}{l}0.126 \\
(0.25) \\
\end{array}$ & $\begin{array}{c}0.27 \\
(0.22) \\
\end{array}$ \\
\hline Intercept & $\begin{array}{c}92.85 * * * \\
(27.39)\end{array}$ & $\begin{array}{c}57.40 * * * \\
(21.38)\end{array}$ & $\begin{array}{l}80.44 * * * \\
(22.47) \\
\end{array}$ & $\begin{array}{l}49.98 * * * \\
(19.03)\end{array}$ & $\begin{array}{l}50.55 * * \\
(20.94)\end{array}$ & $\begin{array}{c}52.34 * * * \\
(19.08)\end{array}$ & $\begin{array}{c}49.48 * * * \\
(18.65)\end{array}$ & $\begin{array}{c}51.77 * * * \\
(17.15)\end{array}$ \\
\hline $\begin{array}{l}\text { Hansen statistic } \\
\text { Prob }>\chi^{2}\end{array}$ & \multicolumn{2}{|c|}{$\begin{array}{c}25.92 \\
0.58 \\
\end{array}$} & \multicolumn{2}{|c|}{$\begin{array}{c}25.14 \\
0.62\end{array}$} & \multicolumn{2}{|c|}{$\begin{array}{c}28.78 \\
0.42 \\
\end{array}$} & \multicolumn{2}{|c|}{$\begin{array}{c}21.51 \\
0.80 \\
\end{array}$} \\
\hline $\mathrm{N}$ & \multicolumn{2}{|c|}{1414} & \multicolumn{2}{|c|}{1203} & \multicolumn{2}{|c|}{1414} & \multicolumn{2}{|c|}{1203} \\
\hline
\end{tabular}

$* * *, * *, *$ significant at respectively $1 \%, 5 \%$ and $10 \%$ level 


\subsection{Collective rationality}

Before comparing the coefficients of the sharing rule across models, we first compute tests of collective rationality for the four models in order to present a further proof that domestic production should be included in the collective approach. Collective rationality implies that $\frac{\partial \psi_{w_{m}}}{w_{f}}=\frac{\partial \psi_{w_{f}}}{w_{m}}$ (equality of the second order crossed derivatives). From equations (13) and (14) we have

$$
\frac{\partial}{\partial w_{f}}\left(\frac{\left(f_{2}+f_{6} \ln w_{f}\right) m_{4}}{w_{m} \Delta}\right)=\frac{\partial}{\partial w_{m}}\left(\frac{\left(m_{1}+m_{6} \ln w_{m}\right) f_{4}}{w_{f} \Delta}-t_{f}\right)
$$

where $\Delta=f_{3} m_{4}-m_{3} f_{4}$. The test of collective rationality is thus

$$
\frac{f_{6} m_{4}}{w_{f} w_{m} \Delta}=\frac{f_{4} m_{6}}{w_{f} w_{m} \Delta}-\frac{\partial t_{f}}{\partial w_{m}}
$$

or

$$
f_{6} m_{4}-f_{4} m_{6}=-w_{f} w_{m} \Delta \frac{\partial t_{f}}{\partial w_{m}}=-w_{f} w_{m}\left(f_{3} m_{4}-m_{3} f_{4}\right) \frac{\partial t_{f}}{\partial w_{m}}
$$

To evaluate the last term we estimate an equation for female domestic time simultaneously with equations (5) and (6), specifying the same set of regressors. Adding a female domestic time equation does not substantially alter the results in Table 3.3, apart from an increase in the effect of the sex-ratio, which remains significant at the $10 \%$-level. The test is then computed at the sample mean. When domestic production is omitted (model 1a and 1b), equation (15) reduces to

$$
f_{6} m_{4}=f_{4} m_{6}
$$

The test shows (see first row of Table 3.3) that collective rationality is unambiguously rejected at the 5\%-level when domestic production is omitted, whereas it cannot be rejected when domestic production is taken into account, even at the $10 \%$-level. This provides another argument in favour of the inclusion of domestic production in collective settings.

\subsection{Recovering the sharing rule}

Using equations (7) to (14), we now compute the derivatives of the sharing rule. Table 3.3 presents the results for the four models, and includes the partial derivatives of the sharing rule. We also provide for each derivative the $\chi_{2}$ statistic of the Wald test of the null 
hypothesis. The partial derivatives represent the change in the non-labour market income share that the wife can claim, as a function of changes in the male wage, the female wage, non-labour income and the sex ratio. The definition of non-labour market income varies across models. It includes the profit from household production in models $2 \mathrm{a}$ and $2 \mathrm{~b}$, while there is no such profit in model 1a and 1b. Nevertheless, in both cases it amounts to "extra labour market income", i.e., the amount of income added, using the sharing rule, to the income earned by each member of the household on the labour market, so that the sum makes up his/her budget constraint.

Table 3.3: Estimation of the sharing rule (marginal effects) and test of collective rationality

\begin{tabular}{|c|c|c|c|c|}
\hline & \multicolumn{2}{|c|}{ Without domestic production } & \multicolumn{2}{|c|}{ With domestic production } \\
\hline & Model 1a & $\begin{array}{l}\text { Model lb } \\
\text { No children } \\
\text { under } 3\end{array}$ & Model 2a & $\begin{array}{l}\text { Model 2b } \\
\text { No children } \\
\text { under } 3\end{array}$ \\
\hline $\begin{array}{l}\text { Tests of collective rationality } \\
\left(\chi_{2} \text { statistic }\right)^{21}\end{array}$ & 4.61 & 4.40 & 0.09 & 0.06 \\
\hline Derivatives of the sharing & $\partial \psi$ & $\partial \psi$ & $\partial \psi$ & $\partial \psi$ \\
\hline & avariable & dvariable & avariable & avariable \\
\hline & $\left(\chi_{2}\right)$ & $\left(\chi_{2}\right)$ & $\left(\chi_{2}\right)$ & $\left(\chi_{2}\right)$ \\
\hline$w_{f}$ & $\begin{array}{l}0.013 \\
(0.98)\end{array}$ & $\begin{array}{l}0.024 \\
(1.55)\end{array}$ & $\begin{array}{l}0.018 \\
(0.70)\end{array}$ & $\begin{array}{l}0.029 \\
(1.11)\end{array}$ \\
\hline$w_{h}$ & $\begin{array}{l}-0.005 \\
(0.23)\end{array}$ & $\begin{array}{l}0.001 \\
(0.02)\end{array}$ & $\begin{array}{l}0.006 \\
(0.21)\end{array}$ & $\begin{array}{l}0.009 \\
(0.39)\end{array}$ \\
\hline $\begin{array}{l}\text { Non labour income } \\
\text { (divided by 100) }\end{array}$ & $\begin{array}{l}0.509 \\
(2.52)\end{array}$ & $\begin{array}{l}0.401 \\
(1.46)\end{array}$ & $\begin{array}{c}0.617 * * \\
(4.86)\end{array}$ & $\begin{array}{c}0.566^{* *} \\
(4.07)\end{array}$ \\
\hline $\begin{array}{c}\text { Sex ratio } \\
\text { (multiplied by } 100)\end{array}$ & $\begin{array}{l}12.60^{*} \\
(3.38)\end{array}$ & $\begin{array}{l}13.07 * \\
(3.02)\end{array}$ & $\begin{array}{l}13.94 * \\
(3.41)\end{array}$ & $\begin{array}{c}16.47^{* * *} \\
(3.88)\end{array}$ \\
\hline
\end{tabular}

**, * significant at respectively the $5 \%$, and $10 \%$ level

The impact of non-labour income is always more significant in the models with household production, indicating that the effects are more precisely estimated when household production is included. The woman's share of a one Euro increase in non-labour income is estimated to be around 60 cents in models $2 \mathrm{a}$ and $2 \mathrm{~b}$ (almost $62 \%$ significantly different from zero in model $2 \mathrm{a}$, and almost $57 \%$ in the case of model $2 \mathrm{~b}$ ). The corresponding 
estimate for models $1 \mathrm{a}$ and $1 \mathrm{~b}$ is between $40 \%$ and $50 \%$, and is not significant. Excluding couples with children under three years slightly reduces the woman's share, but the difference is small and not significant. Moreover, a one percentage point rise in the sex ratio implies that the woman's share in extra labour income rises by slightly less than 200 euros in the models without domestic production (1260 to 1300 French Francs at that time, depending whether or not couples with children under three are included in the sample). This is slightly lower than the increase in model 2a (205 Euros, or 1390 French Francs), and sensibly lower than the increase in model $2 \mathrm{~b}$ (nearly 250 euros, or 1650 French Francs). One explanation for the difference between models $2 \mathrm{a}$ and $2 \mathrm{~b}$ could be that having very young children lowers women's position on the marriage market. This is consistent with the results in Chiappori, Fortin and Lacroix (2002), where distribution factors have a significant effect on the intrahousehold decision process.

We thus find that more robust results are obtained when housework is included in working time than when it is ignored. We find slightly stronger effects for models $2 \mathrm{a}$ and $2 \mathrm{~b}$ than for models $1 \mathrm{a}$ and $1 \mathrm{~b}$, though the results of both models do not appear to be very different when considering the whole sample. The negotiation power of women is always higher, though, when computed in the models including household production, as shown by the robustness of the parameters for non labour income, as well as by their value, always higher in models 2 than in models 1. The difference between the two models appears still stronger when considering the sub-sample consisting of couples without children under 3 only. The finding that models $2 \mathrm{a}$ and $2 \mathrm{~b}$ are more robust than models $1 \mathrm{a}$ and $1 \mathrm{~b}$ is not surprising, since the dependent hours of work variable in model 1a and 1b is clearly not correctly specified. In such a model, it is not impossible to distinguish between the true consumption of leisure and its allocation between partners, and the use of (domestic) time to produce goods and services for all household members.

Why women are found to have a higher negotiation power in models $2 \mathrm{a}$ and $2 \mathrm{~b}$ is less straightforward. On the one hand they consume less leisure (the difference being the time devoted to domestic labour) but on the other hand their labour "earnings" are higher in models $2 \mathrm{a}$ and $2 \mathrm{~b}$ because the value of their domestic labour (evaluated at the woman's wage) is added to their labour market earnings. The finding of a higher negotiation power in models $2 \mathrm{a}$ and $2 \mathrm{~b}$ may be interpreted to indicate that the effect of the latter (higher earnings) outweighs the effect of the former (lower "observed" consumption). An alternative

\footnotetext{
${ }^{21}$ In order to test collective rationality, one equation (on woman's domestic time) has been added in models 2
} 
interpretation could be that the initial share might be much more unequal in favour of men in the model with domestic production than in the model including it. But then, to compensate at least partially for this inequality, their share of any extra euro could be higher in the model with domestic production. As we know nothing about their initial share of income, this interpretation cannot be excluded.

These results suggest that taking into account the whole process of work decisions and exchange within the family has a non negligible impact on the results found for the sharing rule. The analysis of household production would therefore seem essential for an understanding of the intra-household decision process and sharing rule between partners. As households with two-earner couples become the norm, the household sharing rule will increasingly depend on the share of total work, and particularly on the division of domestic work between partners. Note that directly computing the derivatives of the male share instead of the female share gives coherent results, as shown in table A3.1 in appendix 3.

Our empirical findings thus support our results in the theoretical section of the paper: household production matters, and it matters in a way that may invalidate, or at least significantly affect, the results obtained using market work hours only.

\section{Conclusion}

The empirical results presented in this paper provide some evidence that a model which mistakenly interprets non-market time as pure leisure may give misleading results on the intra-household time and resources allocation process. We show how models of collective bargaining may be extended in a simple theoretical and an empirically tractable way by including household production. More specifically, we show that, in the case of marketable goods, the "sharing rule" can be recovered for any bounded household production technology, provided that the Hotelling lemma can be applied (that is, that the derivatives of the profit function exist). We also show that the derivatives of the "sharing rule" can be estimated in a simple way, similar to that used in models based on market time only, and that testable restrictions can be obtained in this case. The main requirement is that time devoted to both domestic and market work must be separately observed for each member of the couple.

We then estimate labour supplies on French time use data both when domestic work is excluded and included. We find that, except for the female wage and for children, most variables exert a similar effect in both cases, though the effects are generally found lower but 
more significant when domestic work is taken into account. The presence of children, and especially of very young children, increases both their father's market work and total work. Conversely, while children also increase their mother's total work, they decrease her labour market work. The same estimations are also made using the sub-sample of couples without children under 3 years old, with the interpretation that young children can be viewed as a case of household public goods, implying a specific division of labour between their parents. The results do not differ significantly from those obtained for the whole sample.

Moreover, we find that collective rationality is rejected when domestic production is omitted, whereas it cannot be rejected when domestic work is included. We suggest that more comparisons should be done using data from other countries.

Finally, we estimate the sharing rule, first assuming that non-market time is "pure leisure" using the same method as in Chiappori, Fortin, and Lacroix (2002), and then, based on our theoretical results, accounting for time inputs in household production. Again, the computation is made using the whole sample, on one hand, and using the sub-sample of couples without young children, on the other hand. When estimated on the full sample, the difference between the results for each model is found not to be very large. When estimated on the sub-sample without children, the difference becomes larger. We interpret this as evidence that household production matters: women are found gaining power when domestic production is taken into account, at least marginally. Moreover, more robust results are obtained when household production is taken into account.

Though this paper shows that household production is important, one must remain cautious about the interpretation of the results, as explained above. More work using time use surveys is needed before any definite conclusions can be drawn. Furthermore, data on the output of household production, in addition to time use survey data, are required, if we are to make serious progress in understanding the intra-household allocation of time and resources.

Acknowledgements We would like to thank Andrew Clark (Paris-Sciences Economiques), Olivier Donni (Université de Cergy) and Guy Lacroix (Université Laval) for helpful comments. We are also grateful to Alessandro Cigno, the editor, as well as to the two anonymous referees for their very valuable comments and suggestions. 


\section{References}

Apps, Patricia F., and Rees, Ray "Taxation and the household," Journal of Public Economics, vol. 35(3), April 1988, 355-369.

Apps, Patricia F., and Rees, Ray «Labour Supply, Household Production and Intra Family Welfare Distribution », Journal of Public Economics, 60, 1996, 199-220

Apps, Patricia F., and Rees, Ray. (1997) "Collective Labor Supply and Household Production", Journal of Political Economy, 105, (February 1997): 178-190.

Apps, Patricia F., and Rees, Ray "Household Production, Full Consumption and the Costs of Children" Labour Economics, 8, , 2002, 621-648.

Aronsson, Thomas; Daunfeldt, Sven-Olov; and Wikström, Magnus. "Estimating intrahousehold allocation in a collective model with household production", Journal of Population Economics, 14 no.4 (December 2001): 569-584.

Bourguignon F. and M.C. Chiuri "Labour Market Time and Home Production: a new test for collective models of intra-household allocation" CSEF Working Paper 131 (2005).

Chiappori, Pierre-André. "Rational Household Labor Supply", Econometrica, 56 (January 1988): 63-89.

Chiappori, Pierre-André. "Collective Labor Supply and Welfare", Journal of Political Economy, 100 (June 1992): 437-467.

Chiappori, Pierre-André. "Introducing Household Production in Collective Models of Labor Supply", Journal of Political Economy, 105 (February 1997): 191-209.

Chiappori, Pierre-André, Blundell, Richard and Meghir, Costas (2002) "Collective Labor Supply with Children", Journal of Political Economy, 113 (December 2005): 1277-1306.

Chiappori, Pierre-André; Fortin, Bernard; and Lacroix, Guy. "Marriage Market, Divorce Legislation and Household Labor Supply". Journal of Political Economy, 110 (February 2002): 37-72.

Couprie, Hélène "Time allocation within the family: welfare implications of life in a couple", Economic Journal, 117, (2007), 287-305.

Donni O. (2003). « The Intrahousehold Allocation of Private and Public Consumption:

Theory and Some Empirical Evidence from U.S. Data ».CIRPEE Working paper 04-02

Donni O. « Labor Supply, Home Production and Welfare Comparisons »The Journal of Public Economics, (2008), forthcoming.

Fortin, B and G Lacroix (1997) "A Test of the Unitary and Collective Models of Household Labour Supply» The Economic Journal, Vol 107, July, pp. 933-955 
Goldschmidt-Clermont, Luisella and Pagnossin-Aligisakis, Elisabetta (1995) "Measures of unrecorded economic activities in fourteen countries" UNDP, Background Papers for the Human Development Report, New York: Oxford UP, 105-155.

Gronau Reuben. (1977), «Leisure, Home Production and Work - The Theory of Allocation of Time Revisited », Journal of Political Economy, 85, December, pp 1099-1123.

Lacroix G., Picot M. et Sofer C. "The Extent of Labour Specialization in the Extended Family: A Theoretical and Empirical Analysis.", Journal of Population Economics, Vol 11, $\mathrm{n}^{\circ} 1$ (1998) p 223-237

Lecocq, Sébastien. "The Allocation of Time and Goods in Household Activities: A Test of Separability", Journal of Population Economics, 14 n $^{\circ} 4$ (December 2001): 585-597.

Manser, Marilyn, and Brown, Murray. "Marriage and Household Decision Making: A Bargaining Analysis", International Economic Review, 21 (February 1980): 31-44.

Marchand O. and Thelot C (1991), «Deux siècles de travail en France », Population active, Insee, Paris.

McElroy, Marjorie B. "The Empirical Content of Nash-bargaining Household Behavior", Journal of Human Resources, 25 (Fall 1990): 559-583.

Pollak, Robert A and Wachter, Michael L. "The Relevance of the Household Production Function and Its Implications for the Allocation of Time," Journal of Political Economy, 83 (April 1975), 255-77.

Rapoport Benoit, Sofer Catherine (2004) «Pure" Production Factors and the Sharing Rule:

Estimating Collective Models with Household Production », Working Paper, MSE, Université Paris1-Panthéon-Sorbonne.

Rizavi S.S. and Sofer C. (2008) "The Division of Labour within the Household: Is There any Escape from Traditional Gender Roles? Working paper, University Paris1.

Robinson, John P., Chenu, Alain and Alvarez, Anthony S. "The Weekly Work Grid: A Measure of the Complexity of Hours at Work", paper presented at IATUR conference, (October 2001) Oslo, Norway, October 3-5.

Samuelson, Paul A. "Social indifference curves", Quarterly Journal of Economics, 70 (February 1956): 1-22.

Sofer, C (1999) " Modélisation économique de la prise de décision dans la famille " in Egalité entre femmes et hommes : aspects économiques, Béatrice Majnoni d'Intignano editor, Conseil d'Analyse Economique, La Documentation Française, Paris.

Sofer C. (2005)《 La croissance de l'activité féminine » in Femmes, genre et sociétés : l'état des savoirs. La Découverte, Paris, pp 218-226. 


\section{Appendix 1}

\section{Proof of Proposition 1:}

Recall that $\psi=\psi_{f}$. We also have: $\psi_{m}=\Pi+y-\psi$

By differentiation of the labour supply equations

$$
\begin{aligned}
& h^{f}=L^{f}\left(w_{f}, \psi\left(w_{f}, w_{m}, y, \ldots s_{l} \ldots ; \mathbf{z}\right) ; \mathbf{z}\right) \\
& h^{m}=L^{m}\left(w_{m}, \Pi\left(w_{f}, w_{m} ; \mathbf{c}, \mathbf{z}\right)+y-\psi\left(w_{f}, w_{m}, y, \ldots s_{l} \ldots ; \mathbf{z}\right) ; \mathbf{z}\right)
\end{aligned}
$$

we obtain:
(3) $\frac{\partial h^{f}}{\partial w_{m}}=\frac{\partial L^{f}}{\partial \psi} \frac{\partial \psi}{\partial w_{m}}$
(3') $\frac{\partial h^{m}}{\partial w_{f}}=\frac{\partial L^{m}}{\partial \psi_{m}}\left(\frac{\partial \Pi}{\partial w_{f}}-\frac{\partial \psi}{\partial w_{f}}\right)$
(4) $\frac{\partial h^{f}}{\partial w_{f}}=\frac{\partial L^{f}}{\partial w^{f}}+\frac{\partial L^{f}}{\partial \psi} \frac{\partial \psi}{\partial w_{f}}$
(4') $\frac{\partial h^{m}}{\partial w_{m}}=\frac{\partial L^{m}}{\partial w^{m}}+\frac{\partial L^{m}}{\partial \psi_{m}}\left(\frac{\partial \Pi}{\partial w_{f}}-\frac{\partial \psi}{\partial w_{m}}\right)$
(5) $\frac{\partial h^{f}}{\partial y}=\frac{\partial L^{f}}{\partial \psi} \frac{\partial \psi}{\partial y}$
(5') $\frac{\partial h^{m}}{\partial y}=\frac{\partial L^{m}}{\partial \psi_{m}}\left(1-\frac{\partial \psi}{\partial y}\right)$
(6) $\frac{\partial h^{f}}{\partial s_{l}}=\frac{\partial L^{f}}{\partial \psi} \frac{\partial \psi}{\partial s_{l}}$
$\left(6^{\prime}\right) \frac{\partial h^{m}}{\partial s_{l}}=\frac{\partial L^{m}}{\partial \psi_{m}}\left(-\frac{\partial \psi}{\partial s_{l}}\right)$

Note that, with reference to the results in Chiappori, Fortin, Lacroix (2002), only (3') and (4') include a new specific term: $\frac{\partial \Pi}{\partial w_{f}}$

Taking the same notation, we define $A=\frac{h_{w_{m}}^{f}}{h_{y}^{f}}, B=\frac{h_{w_{f}}^{m}}{h_{y}^{m}}, C_{l}=\frac{h_{s_{l}}^{f}}{h_{y}^{f}}, D_{l}=\frac{h_{s_{l}}^{m}}{h_{y}^{m}}$. We assume only one distribution factor and suppress the subscripts $l$ and $q$ to simplify the notation. The partial derivative of the sharing rule with respect to wages, non-labour income and the distribution factor are given by:

$\frac{\partial \psi}{\partial y}=\frac{D}{D-C} ; \frac{\partial \psi}{\partial s}=\frac{C D}{D-C} ; \frac{\partial \psi}{\partial w_{m}}=\frac{A D}{D-C}$. Only $\frac{\partial \psi}{\partial w_{f}}$ is modified. From Hotelling's lemma, we obtain: $\frac{\partial \Pi}{\partial w_{f}}=-t_{f}$, and then $\frac{\partial \psi}{\partial w_{f}}$ is given by:

$\frac{\partial \psi}{\partial w_{f}}=\frac{B C}{D-C}-t_{f}$. Note that $t_{f}$ is fully observed in the data. 
The same result holds with several distribution factors. This is a straightforward result from Chiappori, Fortin and Lacroix (2002). Note also that when there is more than one distribution factor, testable restrictions similar to those presented in Chiappori, Fortin and Lacroix (2002) can be derived from the model.

Finally, with no domestic production, the model simplifies to $\Pi=0$, and thus $\frac{\partial \Pi}{\partial w_{f}}=0$, and $\psi$ is now simply non-labour income. In this case (3') reduces to:

$$
\frac{\partial h^{m}}{\partial w_{f}}=\frac{\partial L^{m}}{\partial \psi_{m}}\left(-\frac{\partial \psi}{\partial w_{f}}\right)
$$

and (4') to:

$$
\frac{\partial h^{m}}{\partial w_{m}}=\frac{\partial L^{m}}{\partial w^{m}}+\frac{\partial L^{m}}{\partial \psi_{m}}\left(-\frac{\partial \psi}{\partial w_{m}}\right)
$$

Then $\frac{\partial \psi}{\partial w_{f}}$ reduces to:

$$
\frac{\partial \psi}{\partial w_{f}}=\frac{B C}{D-C}
$$

And thus the formulas in Chiappori, Fortin and Lacroix (2002) are found as a special case of the more general model developed here. 


\section{Appendix 2}

\section{Description of domestic tasks}

Domestic activities include all activities around:

- food and drink: preparation (cutting, cooking, making jam), presentation (laying the table), kitchen and food clean-up (washing up)

- housework: interior cleaning, clothes activities (laundry, mending, sewing, knitting, repairing and maintaining textiles), storing interior household items and tidying

- interior maintenance and repair of house and vehicles: repairing, water and heating upkeep

- household management: financial (bills, count,...)

- shopping

- childcare: physical and medical care, reading, talking with and listening to children, homework help, picking up/dropping off children, playing and leisure with children

- $\quad$ care for household adults

- care for animals and pets

- lawn, garden and houseplants 


\section{Appendix 3}

\section{Computation of the male's share}

Table 3A.1

\begin{tabular}{|c|c|c|c|c|}
\hline $\begin{array}{c}\text { Model 2b } \\
\text { With household } \\
\text { production }\end{array}$ & $w_{f}$ & $w_{h}$ & $\begin{array}{c}\text { Non labour income } \\
\text { (divided by 100) }\end{array}$ & $\begin{array}{c}\text { Sex ratio } \\
\text { (multiplied by 100) }\end{array}$ \\
\hline$\frac{\partial \psi}{\partial \text { variable }}\left(\chi_{2}\right)$ & $\begin{array}{c}-0.026 \\
(1,51)\end{array}$ & $\begin{array}{c}-0.014 \\
(1.03)\end{array}$ & $\begin{array}{c}0.383 \\
(1.88)\end{array}$ & $\begin{array}{c}-13.94 * \\
(3.41)\end{array}$ \\
\hline
\end{tabular}

In table 3A.1, the derivatives of the sharing rule have been computed directly calculating the derivatives of $\Pi+y-\psi$ using formulas symmetrical to those which appear in section 3.3 .

The formulas in appendix 1 show that the derivatives of the sharing rules are not symmetrical for the man and the woman, because of the term $t_{f}$ in the derivative with respect to $w_{f}$. It thus must be checked whether the results are the same when computing directly the derivatives of the male's share. In this latter case, $\psi$ represents now the man's share, and $\Pi+y-\psi$ the woman's share.

As the reduced forms of labour supply are identical, we expect the derivatives with respect to the male and female wages to have an opposite sign and to be about the same absolute value in Table 3.3. The same should hold for the derivative with respect to the sexratio (the coefficient is in fact the exact opposite, see Table 3.3). The derivative with respect to non-labour income is the complement to 1 of the coefficient computed in Table 3.3 ; indeed, we exchange $\psi$ and $\Pi+y-\psi$, so that we exchange $\frac{\partial \psi}{\partial y}$ and $\frac{\partial(\Pi+y-\psi)}{\partial y}=1-\frac{\partial \psi}{\partial y}$ as $\Pi$ does not depend on $y$.

Table 3A.1 presents the results. When comparing with the results of model $2 \mathrm{~b}$ in Table 3.3 , it can be seen that the derivatives relative to wages show, as expected, an opposite sign 
and a similar value: an increase in either the male or the female wage should have an exact opposite effect on the male and the female income share. The same expected result is observed for the sex ratio, where the parameters obtained in the two models are exactly opposite and both significant. As expected also the coefficient found for non labour income is the complement to 1 for the coefficient found in the case of the female's share: when non labour income increases, say by one Euro, then it was found (Table 3.3) that the female share increased by about 62 cents. Here it is found that the male share does increase in that case by $1-62$ cents $=38$ cents. For this coefficient, $\chi_{2}$-tests show that in one hand we cannot reject the null-hypothesis, but in the other hand, the hypothesis that it equals to 1 can be rejected (these are the exact symmetries of the results found in Table 3.3). 